\title{
Occurrence of the cephalopod Martialia hyadesi (Teuthoidea: Ommastrephidae) at the Kerguelen Islands in the Indian Ocean sector of the Southern Ocean
}

\author{
Uwe Piatkowski ${ }^{1}$, Paul G. Rodhouse ${ }^{2}$ and Guy Duhamel ${ }^{3}$ \\ ${ }^{1}$ Institut für Meereskunde der Universität Kiel, Abteilung Fischereibiologie, Düsternbrooker Weg 20, W-2300 Kiel 1 , \\ Federal Republic of Germany \\ ${ }^{2}$ British Antarctic Survey, High Cross, Madingley Road, Cambridge CB3 0ET, UK \\ ${ }^{3}$ Museum National d'Histoire Naturelle, Laboratoire d'Ichtyologie Générale et Appliquée, 43 Rue Cuvier, \\ F-75231 Paris Cedex 05, France
}

Received 25 January 1991; accepted 20 April 1991

\section{Introduction}

In the Atlantic sector of the Southern Ocean, data from vertebrate predators and commercial fisheries suggests that the distribution of the ommastrephid squid Martialia hyadesi is related to the Antarctic Polar Frontal Zone, but it spreads further to the north in some years (Rodhouse, in press). A mass stranding of $M$. hyadesi occurred on Macquarie Island in 1971 (O'Sullivan et al. 1983) suggesting that its distribution is circumpolar (Rodhouse and Yeatman 1990). However, apart from a single beak collected from the stomach of a wandering albatross at Marion Island (Imber and Berruti 1981) its presence has not, until now, been confirmed in the Indian Ocean sector and in particular it is not included in the list of cephalopods from the Kerguelenian Province (Lu and Mangold 1978).

$M$. hyadesi is a major prey item of the grey-headed albatross, Diomedea chrysostoma, and the southern elephant seal, Mirounga leonina, at South Georgia (Rodhouse et al. 1990; Rodhouse et al., unpublished data) and is present in the diet of several other predators in the Scotia Sea area including the wandering albatross, Diomedea exulans (Rodhouse et al. 1987) and the giant petrels, Macronectes halli and $M$. giganteus (Hunter 1983). It occasionally occurs as a significant by-catch in the Illex argentinus fishery on the Patagonian Shelf and has been taken during commercial squid jigging trials in the Scotia Sea at the Antarctic Polar Frontal Zone (Rodhouse, in press). It appears to have potential for commercial exploitation in

Offprint requests to: $\mathrm{U}$. Piatkowski the sub-Antarctic waters of the Atlantic sector of the Southern Ocean (Rodhouse 1990).

In view of the ecological importance of $M$. hyadesi to Antarctic predators, and the likelihood that it will be commercially exploited in the future, it is important to thoroughly establish its geographical range, and in particular to confirm its circumpolar distribution.

\section{Methods and results}

A single specimen of Martialia hyadesi was collected on 23 April 1988 aboard the Soviet trawler KALPER on the Kerguelen Shelf to the north of the Kerguelen Islands at $48^{\circ} 18.4^{\prime} \mathrm{S}, 69^{\circ} 48.9^{\prime} \mathrm{W}$. It was taken at a depth of $140 \mathrm{~m}$ in a bottom trawl with an opening of $42 \mathrm{~m}$ and a mesh size of $80 \mathrm{~mm}$. The main catch consisted of Champsocephalus gunneri $(405 \mathrm{~kg})$, Channichthys rhinoceratus $(182 \mathrm{~kg})$ and Notothenia rossii $(163 \mathrm{~kg})$ and of seven other fish species $(18 \mathrm{~kg})$.

The specimen was a mature male. Measurements taken according to the guidelines of Roper and Voss (1983) are as follows - mantle length: $308 \mathrm{~mm}$; mantle width: $66 \mathrm{~mm}$; fin length: $132 \mathrm{~mm}$; fin width: $186 \mathrm{~mm}$; fin angle $50^{\circ}$; arm I: $125 \mathrm{~mm}$; arm II: 139 ; arm III: $140 \mathrm{~mm}$; arm IV: $102 \mathrm{~mm}$; tentacle: $195 \mathrm{~mm}$; tentacular club: $189 \mathrm{~mm}$. Spermatophores were present in the penis and some had extruded into the mantle cavity. The hectocotylus on the right arm IV was better developed than in previously described specimens (Nesis and Nigmatullin 1972; Rodhouse and Yeatman 1990), with a distinct groove being present on the oral surface on the dorsal side of the dorsal row of trabeculae.

The specimen has been deposited at the Museum National d'Histoire Naturelle, Paris (MNHN squid collection number: 2005).

\section{Discussion}

The capture of this specimen of Martialia hyadesi at the Kerguelen Islands, in the Indian Ocean sector of the 


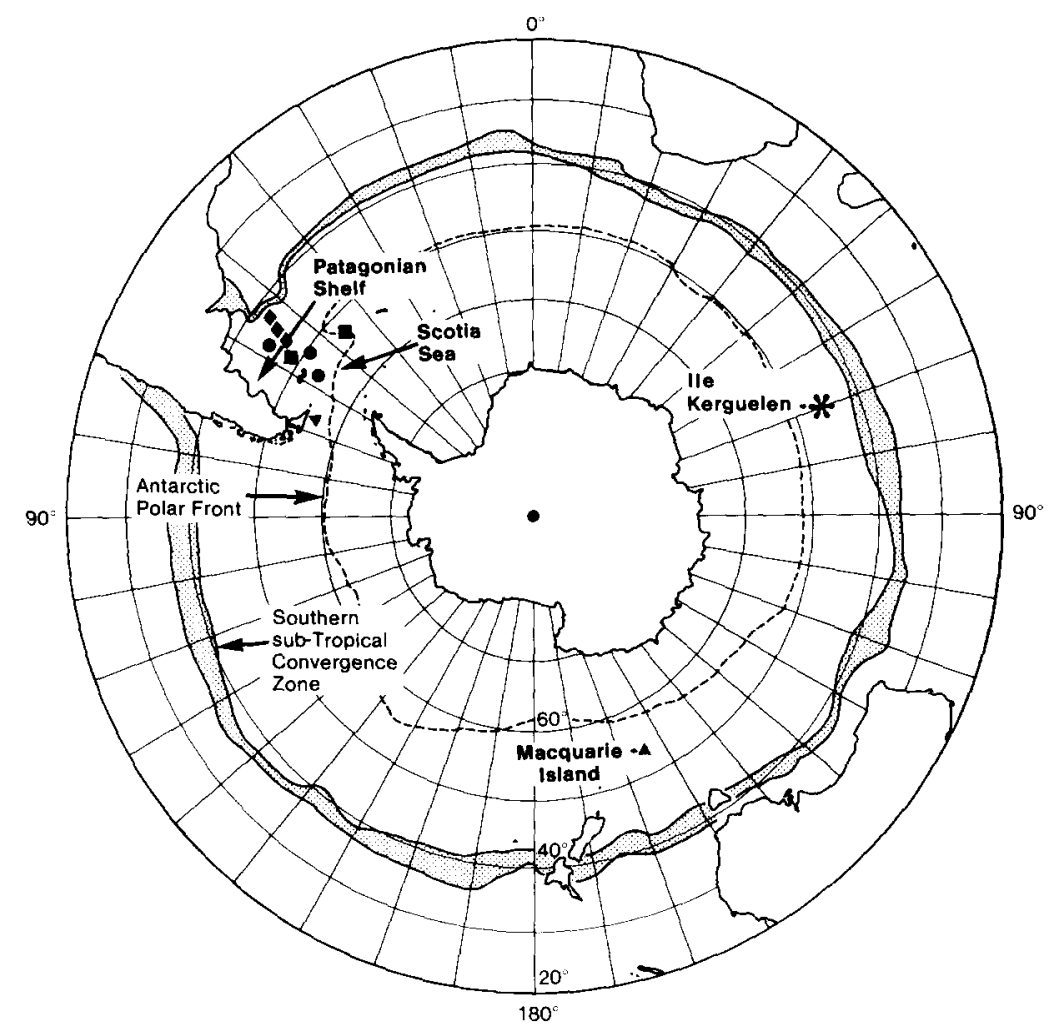

Fig. 1. Map of the Southern Ocean showing known distribution of Martialia hyadesi (* this paper; $\nabla$ Rochebrune and Mabille 1889; Nesis and Nigmatullin 1972; $\Delta$ O'Sullivan et al. 1983; Brunetti et al. 1990; $\mathbf{\square}$ Rodhouse, in press)
Southern Ocean, apparently confirms the circumpolar distribution of the species, linking its known occurrence in the south west Atlantic sector and the western Pacific sector (Fig. 1). Given the areas where it has been caught, it seems likely that this large ommastrephid species, which has a probable life span of two years (Rodhouse, in press) and is closely related to species which are known to make extensive oceanic migrations, has a circumpolar distribution in the Southern Ocean. However, records to date suggest that it is probably associated with island groups in its local distribution.

This specimen is of particular interest because, unlike specimens from the Patagonian Shelf, Scotia Sea and Macquarie Island, it is fully mature. This suggests that it was probably caught in the relatively close vicinity of its spawning ground which may be associated with islands or sea mounts. The life cycle of $M$. hyadesi must be closely related to the West Wind Drift, especially in relation to transport of eggs, larvae and juveniles, but the early life history of the species remains unknown.

Several albatross species in the Indian Ocean Sector of the Southern Ocean have been found to prey on ommastrephid squid (Berruti and Harcus 1978; Brooke and Klages 1986; Weimerskirch et al. 1986). Care is needed in identifying ommastrephid remains in predator gut contents and regurgitations in this area as Todarodes filippovae is also present in the region (Adam 1975). An immature female $T$. filippovae with a mantle length of $353 \mathrm{~mm}$ was taken by KALPER on 28 April 1988 at $48^{\circ} 39.1^{\prime} \mathrm{S}, 70^{\circ} 51.1^{\prime} \mathrm{W}$ at a depth of $125-160 \mathrm{~m}$ with the same gear as the $M$. hyadesi specimen. The two species are therefore sympatric in the vicinity of the Kerguelen Islands.

Acknowledgements. We thank the British Antarctic Survey for supporting Dr. Uwe Piatkowski as a visiting scientist at the Survey's Headquarters in Cambridge in November/December 1990. We are especially grateful to Dr. Andrew Clarke and Mr. Martin White for their assistance in arranging the visit.

\section{References}

Adam W (1975) Notes sur les cephalopodes. XXVI. Une nouvelle espèce de Todarodes (Todarodes filippovae sp. nov.) de l'Ocean Indien. Bull Inst R Sci Nat Belg 50: 1-10

Berruti A, Harcus T (1978) Cephalopod prey of the sooty albatrosses Phoebetria fusca and P. palpebrata at Marion Island. S Afr J Antarct Res 8:99-103

Brooke MdeL, Klages N (1986) Squid beaks regurgitated by greyheaded and yellownosed albatrosses, Diomedea chrysostoma and D. chlororhynchos at the Prince Edward Islands. Ostrich 57:203-206

Brunetti NE, Ivanovic ML, Rossi G (1990) Argentine final report of the Southwestern Atlantic survey by the R/V Kaiyo Maru. Inf Tecnico INIDEP 4:1-49

Hunter S (1983) The food and feeding ecology of the giant petrels Macronectes halli and $M$. giganteus at South Georgia. J Zool London 200:521-538

Imber MJ, Berruti A (1981) Procellariiform seabirds as squid predators. In: Cooper J (ed) Proceedings of the symposium on the birds of the sea and shore. African Seabird Group, Cape Town, pp 43-61

Lu CC, Mangold K (1978) Cephalopods of the Kerguelenian Province of the Indian Ocean. In: Proceedings of the international 
symposium on marine biogeography and evolution in the southern hemisphere, Auckland 17-20 July 1978, vol 2, pp 567-574

Nesis KN, Nigmatullin CM (1972) Demersal squids of the Patagonia - Falkland area. Tr Atl Nauchno-Issled Inst Rybn Khoz Okeanogr 42:170-174

O'Sullivan DB, Johnstone GW, Kerry KR, Imber MJ (1983) A mass stranding of squid Martialia hyadesi Rochebrune and Mabille (Teuthoidea; Ommastrephidae) at Macquarie Island. Pap Proc R Soc Tasmania 117:161-163

Rochebrune AT de, Mabille J (1889) Mollusques. Mission Sci Cap Horn 1882-83 6:1-143

Rodhouse PG (1990) Cephalopod fauna of the Scotia Sea at South Georgia: potential for commercial exploitation and possible consequences. In: Kerry KR, Hempel G (eds) Antarctic ecosystems. Ecological change and conservation. Springer, Berlin Heidelberg New York, pp 289-298
Rodhouse PG (in press) Population structure of Martialia hyadesi (Cephalopoda: Ommastrephidae) at the Antarctic Polar Front and the Patagonian shelf, South Atlantic. Bull Mar Sci

Rodhouse PG, Clarke MR, Murray AWA (1987) Cephalopod prey of the wandering albatross Diomedea exulans. Mar Biol 96:1-10

Rodhouse PG, Prince PA, Clarke MR, Murray AWA (1990) Cephalopod prey of the grey-headed albatross Diomedea chrysostoma. Mar Biol 104:353-362

Rodhouse PG, Yeatman J (1990) Redescription of Martialia hyadesi Rochebrune and Mabille, 1889 (Mollusca: Cephalopoda) from the Southern Ocean. Bull Br Mus Nat Hist (Zool) 56:135-143

Roper CFE, Voss GL (1983) Guidelines for taxonomic descriptions of cephalopod species. Mem Nat Mus Victoria 44:49-63

Weimerskirch H, Jouventin P, Stahl JC (1986) Comparative ecology of the six albatross species breeding on the Crozet Islands. Ibis $128: 195-213$ 